\title{
Attitudes and Self-Efficacy: Perspectives on Science Subjects for Junior High School Students
}

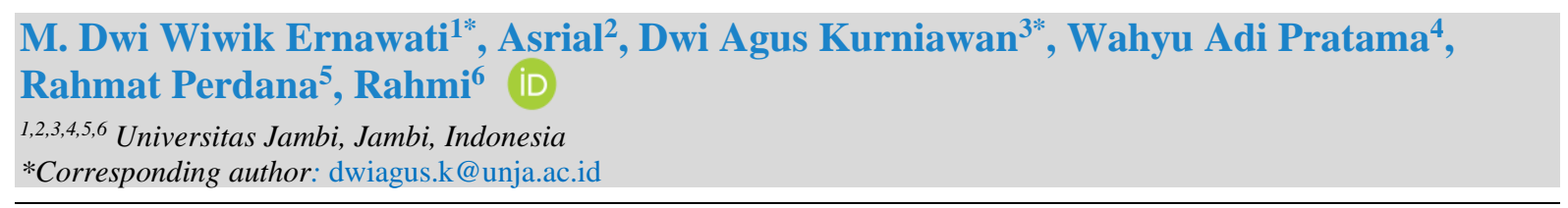

\section{Abstract}

Physics is one of the subjects considered heavy and avoided by some students, which is very challenging, frustrating, perseverance, perseverance, thoroughness and lots of practice so that in reality, not many students like physics. This study aims to determine the differences and the relationship between students' attitudes and self-efficacy in learning science. This type of research is quantitative with a comparative type. The number of respondents used as a sample is 74 students. The data collection technique used simple random sampling. The study results using the T-test showed significant differences in students' attitudes and self-efficacy in science lessons, both female and male students in grade 8A and grade 8B. The correlation test results between students' attitudes and self-efficacy towards science subjects in grade 8A showed that the second variable (attitude and self-efficacy) was related. Moreover, the correlation test results in class $8 \mathrm{~B}$ showed that the two variables (attitude and self-efficacy) were related. The urgency of this research is that teachers can find out the differences in attitudes and self-efficacy between male and female students. Compared to previous research, the novelty of this study is to use Attitude and self-efficacy variables, with different indicators from previous studies.

Keywords: Attitudes, Self-Efficacy, Science

$\begin{array}{ll}\text { History: } & \\ \text { Received } & \text { : July 02, } 2021 \\ \text { Revised } & \text { : July 05, 2021 } \\ \text { Accepted } & \text { : September } 19,2021 \\ \text { Published } & \text { : October } 25,2021\end{array}$

Published : October 25, 2021

\section{INTRODUCTION}

Education very important in the survival of every individual. Education is basically a conscious effort to develop the potential of human resources and create quality human resources, especially students, which is carried out by guiding and facilitating their learning activities (Astalini et al., 2018; Sukendar et al., 2019; Hendri et al., 2020). Education a conscious and planned effort to create a learning atmosphere and learning process according to interests and talents so that students actively develop their potential and ideals. Education a continuous learning process in social activities to acquire knowledge, skills, attitudes and thinking abilities carried out by a person to develop individuals (Hidayat, 2017; Abbas \& Yusuf Hidayat, 2018; Rosidin et al., 2019). Education process of changing attitudes and behavior, forming attitudes, intellectual development, and developing the skills of students in the learning process. Science one part of education that is closely related to everyday life (Brittle, 2020; Tseng et al., 2019).

Natural Sciences closely related to everyday life. Natural Sciences is a learning process that is closely related to the environment and the orderliness of the universe created by God Almighty (Susilawati et al., 2017; Nurmayani et al., 2018; Fitriyah et al., 2019; Puspitasari et al., 2019). Humans can broaden their horizons by using the various kinds of knowledge they have. Natural Sciences plays a role in the development of students' mindsets using scientific concepts (Astalini, Kurniawan, \& Putri, 2018., Bellová et al., 2018., Nielsen et al., 2018). Natural Sciences is a subject that has been studied since elementary school and cannot be separated from the activities of daily life. This lesson is an integrated material 
between biology, physics and chemistry (Abbas \& Yusuf Hidayat, 2018., Sudirman et al., 2020., Winarti, 2021). Physics is one part of science that is very close to everyday life.

Physics is one part of the Natural Sciences which was developed through an inductive approach and has contributed a lot to the development of science and technology. Physics plays an important role in explaining various phenomena that occur in the universe and is one of the sciences that underlies the development of (Halliday \& Resnick, 2014; Istikomah et al., 2020; Sudirman et al., 2020). Physics as one of the natural science studies is in the spotlight in the development of education, especially in learning in schools that are related to various scientific concepts, some of which are applied to increase problem-solving thinking skills that can be found in everyday life (Maison et al., 2018; Manurung \& Panggabean, 2020; Sudirman et al., 2020). Physics is one of the subjects that is considered heavy and is avoided by some students because it is so challenging, sometimes frustrating, it requires perseverance, thoroughness and a lot of practice, so that in reality not many students like physics (Abbas et al., 2018; Astalini, Kurniawan, \& Putri, 2018; Astalini, Kurniawan, \& Sumaryanti, 2018; Putra et al., 2019). Physics is a science that greatly contributes to the development of technology and problem solving can be found in everyday life. In learning Physics, Attitude is one of the determining factors for the success of learning Physics.

Attitudes are all actions and actions that are based on the convictions and beliefs they have. Attitude is one of the factors that influence the learning process that comes from within students (Maison et al., 2018; Puspitasari et al., 2019; Sukendar et al., 2019). Students' attitudes when solving problems faced by students can affect their success in solving problems (Hamdani et al., 2017; Sappaile, 2017; Puspitasari, Sari, et al., 2019). Positive attitudes that arise, for example, enthusiasm during teaching and learning activities, a sense of pleasure and curiosity about physics subject matter. Meanwhile, negative attitudes that arise include lack of interest in taking lessons, lazy to listen to teacher explanations, not enthusiastic and bored during the physics learning process (Maison et al., 2018; Kurniawan et al., 2019; Sakliressy et al., 2021). Besides attitude, another factor that can affect learning outcomes is self-efficacy.

Self efficacy (self-ability) itself is a belief that a person has in his or her own ability to do something (Trautner \& Schwinger, 2020). learning models can also be influenced by student characteristics, one of which is self-efficacy (Aharony \& Gazit, 2020; Hasyim \& Eldiana, 2020; Wong et al., 2020). The term "self-efficacy" is used to describe students' beliefs that their actions can produce something desired such as solving problem difficulties, confidence in the chosen answer or achieving goals (Susongko \& Afrizal, 2018; Latifah et al., 2019; Mayasari et al., 2019). Self-efficacy plays an important role in stimulating students to increase their sense of enthusiasm in learning (Sökmen, 2021; Zysberg \& Schwabsky, 2020; Gundel et al., 2019). The success of a person's learning is determined by the affective domain that has low self-efficacy and will easily give up and tend not to solve problems (Mafaza et al., 2018; Hendriana \& Kadarisma, 2019; Nurani et al., 2021). Each individual has a different level of self-ability, even from the gender differences of each individual.

Gender is a set of characteristics that distinguish masculinity and femininity, people often view a person's gender as an important predictor of a person's abilities. Gender equality is a world priority in the welfare of society, especially in terms of education in the acquisition of student achievement Gender is defined as a factor that affects a person's belief in something and will ultimately affect a person's behavior (Pieh et al., 2020; Resty et al., 2019). The difference in the quality of the learning process of male students and female students based on gender class is very important to note, gender has a direct influence on student learning achievement. Gender factors are also important to note (Josephidou, 2020; Ndayambaje et al., 2020; Nurul Lathifatul Hakimah et al., 2020). Gender does not only mean 
gender, but also the psychosocial aspects of men and women, so that gender and gender are interrelated terms.

The research conducted by the researcher is in line with previous research, states that self-efficacy is a factor that can influence various individual actions (Hamdani et al, 2017; Gasila et al, 2019; Latipah et al, 2020). Self-efficacy as an internal factor. If the self-efficacy factor is owned by the individual, it can help the individual in achieving the desired goal. In addition, research states that attitude is important in the learning and learning process (Sukendar et al, 2019; Ridlo, 2020). The attitude of students is very necessary because attitudes will affect student learning outcomes. However, previous studies did not link the differences and relationships between these two variables with other indicators and differentiating factors as in this study. The purpose of this study is to find out whether there is a relationship between attitudes and self-efficacy of junior high school students in science subjects. The novelty of this study is to use the Attitude and self-efficacy variables, with different indicators from previous research.

\section{METHODS}

This study uses quantitative and comparative research using survey procedures. In this case, surveys are a good procedure to use. The type of research used uses survey research types and quantitative and comparative designs. In essence, qualitative research observes people in the environment as well as in the social sciences (Wu et al., 2019., Aranda et al., 2020; Rafiee et al., 2020). This research gains an understanding of a phenomenon from basic logic, usually includes the perspective of the research population (Albi \& Johan, 2018; Rahmaningrum et al., 2020). It also aims to find similarities from the population by looking at its comparison to a predetermined standard with Thus this study will measure how the comparison of students' attitudes and self-efficacy towards science subjects at Junior High School 7 Muaro Jambi.

The sample in this study was 74 students from Junior High School 7 Muaro Jambi in Muaro Jambi Regency. The population is the person who is the subject of research or the characteristics to be studied (Banks et al., 2018; Novianti et al., 2019; Sari et al., 2020). The sampling technique is purvosive sampling. The reason for taking this technique is because not all samples have criteria that match the phenomenon being studied. The samples taken were students in grades $8 \mathrm{~A}$ and $8 \mathrm{~B}$ consisting of 40 girls and 34 boys.

There are two instruments in this study, namely attitudes towards science and selfefficacy. The assessment instrument is one of the most important assessment instruments for attitudes. The focus of this research is on 7 dimensions of attitude, namely the implications of science questions, normality of scientists, attitudes towards science investigations, adoption of scientific attitudes, Next for the self-efficacy indicator, the indicators are the strength and weakness of beliefs, individual expectations of abilities, making experience in as a basis for increasing confidence. For the questionnaire grid for this research, it can be seen in table 1.

Table 1. Grid of Student Attitude Questionnaire Instruments in Science Subjects

\begin{tabular}{|c|c|c|c|}
\hline \multirow{2}{*}{ Variable } & \multirow{2}{*}{ Indicator } & \multicolumn{2}{|c|}{ No. Statement Items } \\
\hline & & $(+)$ & $(-)$ \\
\hline \multirow{5}{*}{$\begin{array}{l}\text { Students' } \\
\text { attitudes } \\
\text { towards } \\
\text { science } \\
\text { subjects }\end{array}$} & Social Implications of IPA & $1,14,27,39$ & $7,20,32,45,53$ \\
\hline & Scientist Normality & $8,21,33,46,54$ & 15,40 \\
\hline & $\begin{array}{l}\text { Attitude Towards Science } \\
\text { Investigation }\end{array}$ & 2,41 & $9,22,34,47,55$ \\
\hline & Adopt Scientific Attitude & $3,26,28$ & $10,23,35,48$ \\
\hline & Fun in Learning Science & $4,17,29$ & $11,24,36,42,49,56$ \\
\hline
\end{tabular}




\begin{tabular}{llll}
\hline \multirow{2}{*}{ Variable } & \multicolumn{1}{c}{ Indicator } & \multicolumn{2}{c}{ No. Statement Items } \\
\cline { 2 - 4 } & \multicolumn{1}{c}{$(+)$} & $\mathbf{( - )}$ \\
\cline { 2 - 4 } & Interest in increasing the time to & $5,18,30$ & $12,25,37,43,50$ \\
& $\begin{array}{l}\text { study science } \\
\text { Interest in a Career in Science }\end{array}$ & $13,19,26,38,6,31,44,52$ \\
& 51 & $\mathbf{2 5}$ & $\mathbf{3 1}$ \\
\hline
\end{tabular}

Table 2. Grid of Student Self-efficacy Questionnaire Instruments in Science Subjects

\begin{tabular}{cll}
\hline Variable & Indicator & \multicolumn{1}{c}{$\begin{array}{c}\text { No. Statement } \\
\text { Items }\end{array}$} \\
\hline & Task Difficulty Level & $1,2,3$ \\
Students' & Behavior or Attitude Shown in the Face of Tasks. & $4,5,6,7$ \\
attitudes & Strong Weak Faith & $8,9,10,11,12$ \\
towards & Individual Expectations of Ability & $13,14,15,16,17,18$ \\
science & Taking Experience Not as an Obstacle & $19,20,21,22,23$ \\
subjects & Making Inner Experience The Basis To Increase & $24,25,26,27,28$ \\
& Confidence & $\mathbf{2 8}$ \\
\hline
\end{tabular}

Sample identification or specification, data collection, database construction, data analysis, result dissemination, and data sharing. The sampling technique was adopted because it provides unbiased parameter estimates and is better if the population is homogeneous. This research was carried out starting from mentioning the questionnaire or questionnaire, then quantitative and comparative data analysis was carried out. Next, identify the results for follow-up. At the data collection stage, questionnaires were given to 74 students at one Junior High School 7 Muaro Jambi school in Muaro Jambi district. From this data, data analysis is then carried out, namely data coding, filtering appropriate data and analyzing the data.

Although the researcher can choose between several available analytical techniques, procedures for making comparisons, asking questions, and sampling based on evolving theoretical concepts are important features of the methodology. In collecting data in the form of attitude activities carried out using descriptive statistics based on the categories given by the researcher. The data needed in this research were collected and obtained from Junior High School 7 Muaro Jambi. There is also the procedure for collecting data in this research in accordance with the following diagram:
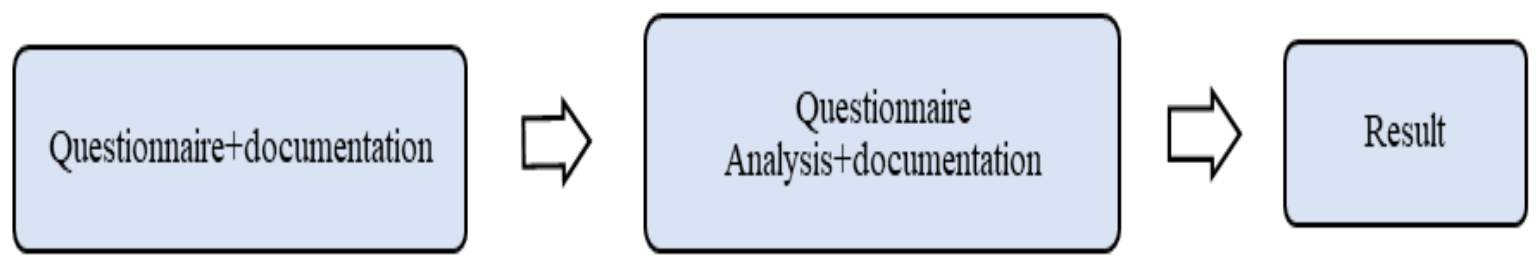

Figure 1. Research procedure 


\section{RESULTS AND DISCUSSION}

\section{Results}

In the results, we will discuss descriptive statistical tests of variables, Assumptions Test (normality, homogeneity and linearity), and Hypothesis Testing ( $\mathrm{T}$ test and correlation test). There are also indicators about the attitude taken, namely: social implications of science, normality of scientists, attitudes towards science investigations, adoption of scientific attitudes. indicators on self-efficacy, namely: Strong and weak beliefs, Individual expectations of abilities, making internal experience as a basis for increasing confidence.

Based on the results of data analysis, in class 8A male students are dominant in the good category while female students still have bad attitudes and are dominant in the good category, in class $8 \mathrm{~B}$ the results are that students in the class of students are dominant in the good category and for male students in the good category, but there are those in the bad category. The class $8 \mathrm{~A}$ female students are dominant in the good category while female students dominant in the good category, in class $8 \mathrm{~B}$ the results are that students in the class of students are dominant in the good category and for male students in the good category, but there are those in the bad category. The class 8A male students are dominant in the good category while female students still have bad attitudes and are dominant in the good category, in class 8B the results are that students in the class of students are dominant in the good category and for male students in the good category, but there are those in the bad category.

In class 8A male students are dominant in the good category while female students still have bad attitudes and are dominant in the good category, in class $8 \mathrm{~B}$ the results are that students in the class of students are dominant in the good category and for male students in the good category, but there are those in the bad category. Class 8A male students are dominant in the good category while female students still have bad attitudes and are dominant in the good category, in class $8 \mathrm{~B}$ the results are that students in the class of students are dominant in the good category and for male students in the good category, but there are those in the bad category. In class $8 \mathrm{~A}$ male students are dominant in the good category while female students still have bad attitudes and are dominant in the good category, in class 8B the results are that students in the class of students are dominant in the good category and for male students in the good category, but there are those in the bad category. Class 8A male students are dominant in the good category while female students still have bad attitudes and are dominant in the good category, in class $8 \mathrm{~B}$ the results are that students in the class of students are dominant in the good category and for male students in the good category, but there are those in the bad category.

The normality test was obtained with the Kolmogorov-Smoniv test, the significance value $>$ from 0.05 , it can be concluded that the data is normally distributed. The attitude and self-efficacy data of grade $8 \mathrm{~A}$ and $8 \mathrm{~B}$ students are homogeneous as evidenced by the value of sig $>0.05$. The significance value has met the requirements $<0.05$, then the data meets the linear rule, so it can be concluded that there is a linear relationship between attitudes and selfefficacy in class $8 \mathrm{~A}$ and $8 \mathrm{~B}$. There is a significant difference between the attitudes and self efficacy of male students and female students in grade $8 \mathrm{~A}$ and $8 \mathrm{~B}$. The requirements $<0.05$, it can be concluded that there is relationship between attitudes and self-efficacy of male and female students in grade 8A and 8B.

Descriptive statistics are methods related to the collection and presentation of a data set so as to provide useful and easy-to-understand information. In this study, researchers used 4 attitude indicators and 3 self-efficacy indicators. In the descriptive statistical test of attitude indicators of social implications, it was found that in class $8 \mathrm{~A}$ the dominant male students were better with a good percentage of $58 \%$ and in class $8 \mathrm{~B}$ the dominant female students were better with a good percentage of $55 \%$. In the normality indicator, scientists found that in class $8 \mathrm{~A}$ the dominant male students were better with a percentage of $64 \%$ good and in class 
8B the dominant female students were better with a good percentage of $75 \%$. In the Attitude indicator towards science investigations, it was found that in class $8 \mathrm{~A}$ the dominant female students were better with a percentage of $60 \%$ good and in grade $8 \mathrm{~B}$ the dominant male students were better with a percentage of $70 \%$ good. In the Adoption indicator of scientific attitude, it was found that in class $8 \mathrm{~A}$ the dominant female students were better with a percentage of $50 \%$ good and in grade $8 \mathrm{~B}$ the dominant female students were better with a percentage of $60 \%$ good.

In the descriptive statistical test of the self-efficacy indicator of the strength and weakness of belief, it was found that in class $8 \mathrm{~A}$ the dominant male students were better with a percentage of $64 \%$ good and in class $8 \mathrm{~B}$ the dominant male students were better with a good percentage of $64 \%$. In the individual expectation indicator on ability, it was found that in class $8 \mathrm{~A}$ the dominant male students were better with a good percentage of $50 \%$ and in class $8 \mathrm{~B}$ the dominant female students were better with a good percentage of $57 \%$. In the indicator Using internal experience as the basis for increasing confidence, it was found that in class $8 \mathrm{~A}$ the dominant male students were better with a percentage of $57 \%$ good and in class $8 \mathrm{~B}$ the dominant female students were better with a good percentage of $55 \%$.

In the Assumption test, the researcher uses the normality test, homogeneity test, and linearity test. In the attitude normality test, the normality test was obtained with the Kolmogorov-Smoniv test with a significance value of $>0.05$, so it can be concluded that the data is normally distributed. In the self-efficacy normality test, the normality test was obtained with the Kolmogorov-Smoniv test with a significance value of $>0.05$, so it can be concluded that the data is normally distributed. In the homogeneity test for class 8A, it can be seen that the attitude and self-efficacy data of class $8 \mathrm{~A}$ students are homogeneous, as evidenced by the value of sig $>0.05$. In the homogeneity test for class $8 \mathrm{~B}$, it can be seen that the attitude and self-efficacy data of class 8B students are homogeneous, as evidenced by the value of sig $>0.05$. In the Class $8 \mathrm{~A}$ Linearity Test, a significance value that has met the requirements $<0.05$, then the data meets the linear rule, so it can be concluded that there is a linear relationship between attitudes and self-efficacy in class 8A. In the Linearity Test for class $8 \mathrm{~B}$, a significance value that has met the requirements $<0.05$ was obtained, then the data met the linear rule, so it can be concluded that there is a linear relationship between attitudes and self-efficacy in class $8 \mathrm{~B}$.

In the hypothesis test, the researcher used the $\mathrm{T}$ test and the Correlation Test, in the $\mathrm{T}$ test the attitude of the $8 \mathrm{~A}$ grade students obtained a significance value that had met the requirements $<0.05$, it can be concluded that there was no difference between the attitudes of male students and female students in grade 8A. In the T-test of the attitudes of the 8B students, a significance value that has met the requirements $<0.05$ was obtained, it can be concluded that there is no difference between the attitudes of male and female students in 8B. In the self-efficacy $\mathrm{T}$ test for class $8 \mathrm{~A}$, a significance value that has met the requirements < 0.05 was obtained, it can be concluded that there is no difference between the self-efficacy of male students and female students in grade $8 \mathrm{~A}$. In the self-efficacy $\mathrm{T}$ test for class $8 \mathrm{~B}$, a significance value that has met the requirements $>0.05$ was obtained, it can be concluded that there is no difference between the self-efficacy of male students and female students in grade 8B. In the Correlation test class $8 \mathrm{~A}$ obtained a significance value that has met the requirements $<0.05$, it can be concluded that there is no relationship between attitudes and self-efficacy of male and female students in grade 8A. In the Correlation test class $8 \mathrm{~B}$ obtained a significance value that has met the requirements $<0.05$, it can be concluded that there is no relationship between attitudes and self-efficacy of male and female students in grade $8 \mathrm{~B}$. 


\section{Discussion}

The research conducted by the researcher is in line with previous research, including whose conclusion states that self-efficacy is a factor that can influence various individual actions (Hamdani et al 2017; Gasila et al., 2019; Latipah et al., 2020). Self-efficacy as an internal factor. If the self-efficacy factor is owned by the individual, it can help the individual in achieving the desired goal. In addition, the attitude variable is in line with research which states that attitude is important in the learning and learning process. The attitude of students is very necessary because attitudes will affect student learning outcomes (Sukendar et al., 2019; Ridlo, 2020).

The research conducted by the researcher is in line with previous research, states that self-efficacy is a factor that can influence various individual actions (Hamdani et al 2017; Gasila et al., 2019; Latipah et al., 2020). Self-efficacy as an internal factor. If the self-efficacy factor is owned by the individual, it can help the individual in achieving the desired goal (Öztürk et al., 2020; Sun \& Wang, 2020; Wilde \& Hsu, 2019). The attitude of students is very necessary because attitudes will affect student learning outcomes (Dahniar, 2019; Memiş \& Kandemir, 2019; Wijaya et al., 2020). The novelty of this research compared to previous research is that it uses Attitude and self-efficacy variables, with different indicators from previous research and this research is a generalization of previous research. The urgency of this research is that teachers can find out the differences in attitudes and selfefficacy between male and female students.

Research conducted by researchers is about the relationship between attitudes and self-efficacy on learning outcomes in science subjects, so this can be the basis and reference in conducting research to investigate further about learning attitudes and self-efficacy with science learning outcomes. In this study, 7 indicators are used, there are 4 attitude indicators and 3 indicators of self-efficacy used. In this study, researchers measured students' attitudes towards science as the object. The essence of measuring attitudes in schools is useful for knowing the feelings of students during the science learning process, both in the form of positive attitudes and negative attitudes, and it is hoped that students have positive attitudes towards science/science. Because, if students have a positive attitude towards science, it will affect students' abilities and results in science subjects at school. This research can also help teachers analyze the effect of self-efficacy and student attitudes towards learning at school and students to understand students' problems in science lessons in several educational development courses.

\section{CONCLUSION}

The results showed that there were significant differences between male and female students' attitudes towards science learning in grade $8 \mathrm{~A}$ or grade $8 \mathrm{~B}$. Both sexes have different attitudes and self-efficacy towards science learning. On the results of the attitude of female students have a higher good presentation than the male presentation. While the percentage of self-efficacy in both men is more dominant than women. With the difference in the high and low values of attitude and self-efficacy, students will be more thorough and responsive to the given science assignments. However, it is expected that even though they have low attitudes and self-efficacy values, they do not always have a negative influence on students' attitudes or views on science subjects.

\section{REFERENCES}

Abbas, A., \& Yusuf Hidayat, M. (2018). Faktor-Faktor Kesulitan Belajar Fisika Pada Peserta Didik Kelas IPA Sekolah Menengah Atas. JPF (Jurnal Pendidikan Fisika) 
Universitas Islam Negeri Alauddin Makassar. https://doi.org/10.24252/jpf.v6i1a8.

Aranda, M., Gracia, F. J., Peralta, G., \& Flor-Blanco, G. (2020). The Application of HighResolution Mapping for the Analysis of Recent Eco-Geomorphological Changes in the Saltmarshes of San Vicente de la Barquera Estuary (North Spain). Journal of Coastal Research. https://doi.org/10.2112/S195-066.1.

Astalini, A., Kurniawan, D. A., \& Putri, A. D. (2018). Identifikasi Sikap Implikasi Sosial dari IPA, Ketertarikan Menambah Waktu Belajar IPA, dan Ketertarikan Berkarir Dibidang IPA Siswa SMP Se-Kabupaten Muaro Jambi. Jurnal Tarbiyah: Jurnal Ilmiah Kependidikan, 7(2), 93-108. https://doi.org/10.18592/tarbiyah.v7i2.2142.

Astalini, A., Kurniawan, D. A., \& Sumaryanti, S. (2018). Sikap Siswa Terhadap Pelajaran Fisika di SMAN Kabupaten Batanghari. JIPF (Jurnal Ilmu Pendidikan Fisika). https://doi.org/10.26737/jipf.v3i2.694.

Banks, H. T., Flores, K. B., Langlois, C. R., Serio, T. R., \& Sindi, S. S. (2018). Estimating the rate of prion aggregate amplification in yeast with a generation and structured population model. Inverse Problems in Science and Engineering, 26(2), 257-279. https://doi.org/10.1080/17415977.2017.1316498.

Brittle, B. (2020). Coping strategies and burnout in staff working with students with special educational needs and disabilities. Teaching and Teacher Education, 87. https://doi.org/10.1016/j.tate.2019.102937.

Dahniar, A. (2019). Memahami Pembentukan Sikap (Attitude) Dalam Pendidikan Dan Pelatihan. Tatar Pasundan: Jurnal Diklat Keagamaan, 13(2), 202-206. https://doi.org/10.38075/tp.v13i2.27.

Fitriyah, A. L., Jufriadi, A., \& Pratiwi, H. Y. (2019). Pengembangan Modul Ipa Fisika Berbasis Asesmen Autentik Untuk Siswa SMP/MTs. Kelas VII. RAINSTEK : Jurnal Terapan Sains \& Teknologi. https://doi.org/10.21067/jtst.v1i2.3428.

Gasila, Y., Fadillah, S., \& Wahyudi. (2019). Analisis Keterampilan Proses Sains Siswa Dalam Menyelesaikan Soal IPA Di SMP Negeri Kota Pontianak. Jurnal Inovasi Dan Pembelajaran Fisika (JIPF). https://doi.org/10.36706/jipf.v6i1.10399.

Halliday, D., \& Resnick, R. (2014). Fundamentals of Physics 10th ed. In Wiley.

Hamdani, H., Mursyid, S., Sirait, J., \& Etkina, E. (2017). Analisis Hubungan antara Sikap Penyelesaian Soal dan Hasil Belajar Mahasiswa Calon Guru Fisika. Jurnal Penelitian \& Pengembangan Pendidikan Fisika. https://doi.org/10.21009/1.03205.

Hasyim, M., \& Eldiana, N. F. (2020). Eksperimentasi model PBL dan PjBL berbasis schoology terhadap pemecahan masalah matematika ditinjau dari self-efficacy. $J P 2 M$ (Jurnal Pendidikan Dan Pembelajaran Matematika). https://doi.org/10.29100/jp2m.v6i2.1751.

Hendri, M., Pramudya, L., Ika, N., \& Pratiwi, S. (2020). Analisis hubungan karakter semangat kebangsaan dengan hasil belajar siswa. Jurnal Pembangunan Dan Pendidikan: Fondasi Dan Aplikasi, 7(1), 1-8. http://dx.doi.org/ 10.21831/jppfa.v7i1.25209.

Hendriana, H., \& Kadarisma, G. (2019). Self-Efficacy dan Kemampuan Komunikasi Matematis Siswa SMP. JNPM (Jurnal Nasional Pendidikan Matematika), 3(1), 153. https://doi.org/10.33603/jnpm.v3i1.2033.

Hidayat, W. (2017). Adversity Quotient Dan Penalaran Kreatif Matematis Siswa Sma Dalam Pembelajaran Argument Driven Inquiry Pada Materi Turunan Fungsi. Jurnal Pendidikan Matematika. 2(1), 15-28 https://doi.org/10.22236/kalamatika.

Josephidou, J. (2020). A gendered contribution to play? Perceptions of Early Childhood Education and Care (ECEC) practitioners in England on how their gender influences their approaches to play. Early Years. https://doi.org/10.1080/09575146.2019.1655713. 
Kurniawan, D. A., Astalini, A., Kurniawan, N., \& Pathoni, H. (2019). Analisis korelasi sikap siswa dan disiplin siswa terhadap IPA pada Siswa SMP Provinsi Jambi. Jurnal Pendidikan Fisika Dan Keilmuan (JPFK). https://doi.org/10.25273/jpfk.v5i2.5014.

Latifah, S., Susilowati, N. E., Khoiriyah, K., Saidy, S., Yuberti, Y., \& Rahayu, R. (2019). Self-Efficacy: Its Correlation to the Scientific-Literacy of Prospective Physics Teacher. Journal of Physics: Conference Series. https://doi.org/10.1088/17426596/1155/1/012015.

Latipah, E., Kistoro, H. C. A., \& Khairunnisa, I. (2020). Scientific Attitudes in Islamic Education Learning: Relationship and the Role of Self-Efficacy and Social Support. Edukasia: Jurnal Penelitian Pendidikan Islam. https://doi.org/10.21043/edukasia.v15i1.7364.

Mafaza, M., Anggreiny, N., \& Alfara, H. (2018). Parenting Self Efficacy pada Orang Tua dengan Tuna Netra. Jurnal Ilmu Perilaku, I(2), 110. https://doi.org/10.25077/jip.1.2.110-124.2017.

Mahmudi, M. H., \& Suroso. (2014). Efikasi Diri , Dukungan Sosial Dan Penyesuaian Diri Dalam Belajar. Persona, 3(02), 183-194. https://doi.org/10.30996/persona.v3i02.382.

Maison, Astalini, Kurniawan, D. A., \& Sholihah, L. R. (2018). Deskripsi Sikap Siswa Sma Negeri Pada Mata Pelajaran Fisika. Jurnal Eduasains, 10(1). https://doi.org/10.15408/es.v10i1.7214.

Manurung, S. R., \& Panggabean, D. D. (2020). Improving students' thinking ability in physics using interactive multimedia based problem solving. Cakrawala Pendidikan. https://doi.org/10.21831/cp.v39i2.28205.

Mayasari, D., Muliyani, R., Kurniawan, Y., \& Istirahayu, I. (2019). Physics Achievement Test Implies Students' Self-Efficacy on Decision Making Process. JIPF (Jurnal Ilmu Pendidikan Fisika). https://doi.org/10.26737/jipf.v4i2.955.

Memiş, A. D., \& Kandemir, H. (2019). The Relationship Between the Study Habits and Attitudes and Metacognitive Reading Comprehension Self-Awareness, Reading Comprehension, Reading Attitudes. World Journal of Education, 9(4), 133. https://doi.org/10.5430/wje.v9n4p133.

Ndayambaje, E., Nkundimana, B., Pierewan, A. C., Nizeyumukiza, E., \& Ayriza, Y. (2020). Marital status and subjective well-being: Does education level take into account? Cakrawala Pendidikan. https://doi.org/10.21831/cp.v39i1.29620.

Novianti, R. W., Triwani, T., \& Roflin, E. (2019). Characteristic Patients With Urogenital System Congenital Abnormalities In At RSMH Palembang. Majalah Kedokteran Sriwijaya. https://doi.org/10.32539/mks.v51i2.8542.

Nurani, M., Riyadi, R., \& Subanti, S. (2021). Profil Pemahaman Konsep Matematika Ditinjau Dari Self Efficacy. AKSIOMA: Jurnal Program Studi Pendidikan Matematika, 10(1), 284. https://doi.org/10.24127/ajpm.v10i1.3388.

Nurmayani, L., Doyan, A., \& Sedijani, P. (2018). Pengaruh Model Pembelajaran Inkuiri Terbimbing Terhadap Hasil Belajar Fisika Peserta Didik. Jurnal Penelitian Pendidikan IPA. https://doi.org/10.29303/jppipa.v4i2.113.

Nurul Lathifatul Hakimah, Nur Kuswanti, \& Andri Wahyu Wijayadi. (2020). Pengaruh Gender Terhadap Hasil Belajar Siswa Kelas Vii Smp Darul Ulum 5 Jombang Mata Pelajaran IPA Materi Pemanasan Global Menggunakan Model Pembelajaran Discovery Learning. Ed-Humanistics: Jurnal Ilmu Pendidikan. https://doi.org/10.33752/ed-humanistics.v5i1.701.

Öztürk, M., Akkan, Y., \& Kaplan, A. (2020). Reading comprehension, Mathematics selfefficacy perception, and Mathematics attitude as correlates of students' non-routine Mathematics problem-solving skills in Turkey. International Journal of Mathematical Education in Science and Technology, 51(7), 1042-1058. 
https://doi.org/10.1080/0020739X.2019.1648893.

Pieh, C., Budimir, S., \& Probst, T. (2020). The effect of age, gender, income, work, and physical activity on mental health during coronavirus disease (COVID-19) lockdown in Austria. Journal of Psychosomatic Research. https://doi.org/10.1016/j.jpsychores.2020.110186.

Puspitasari, T. O., Putri, Y. E., \& Yohanes, Y. (2019). Sikap Terhadap Konsentrasi Belajar Siswa Pada Mata Pelajaran Fisika di Sekolah Menengah Atas. JIPFRI (Jurnal Inovasi Pendidikan Fisika Dan Riset Ilmiah). https://doi.org/10.30599/jipfri.v3i2.537.

Puspitasari, T. O., Sari, N., Putri, Y. E., \& Jannah, N. (2019). Attitude; Physics Learning Concentration. COMPTON: Jurnal Ilmiah Pendidikan Fisika. https://doi.org/10.30738/cjipf.v6i2.5850.

Putra, D. S., Lumbantoruan, A., \& Samosir, S. C. (2019). Deskripsi Sikap Siswa: Adopsi Sikap Ilmiah, Ketertarikan Memperbanyak Waktu Belajar Fisika dan Ketertarikan Berkarir di Bidang Fisika. Tarbiyah: Jurnal Ilmiah Kependidikan. https://doi.org/10.18592/tarbiyah.v8i2.3339.

Rahmaningrum, H., Harmayetty, Yasmara, D., \& Krisnana, I. (2020). Factors analysis related to the completeness of providing basic immunization in infant aged 12 months. Medico-Legal Update. https://doi.org/10.37506/mlu.v20i3.1454.

Resty, Z. N., Muhardjito, M., \& Mufti, N. (2019). Discovery Learning Berbantuan Schoology: Upaya Peningkatan Kemampuan Berpikir Kritis. Jurnal Pendidikan: Teori, Penelitian, Dan Pengembangan. https://doi.org/10.17977/jptpp.v4i2.12040.

Ridlo, A. (2020). Deskripsi sikap siswa dalam mata pelajaran ipa di smp it ashidiqi. Journal Evaluation in Education (JEE). https://doi.org/10.37251/jee.v1i2.42.

Rosidin, U., Kadaritna, N., \& Hasnunidah, N. (2019). Can argument-driven inquiry models have impact on critical thinking skills for students with differentpersonality types? Cakrawala Pendidikan. https://doi.org/10.21831/cp.v38i3.24725.

Sakliressy, M. T., Sunarno, W., \& Nurosyid, F. (2021). Students Scientific Attitude in Learning Physics Using Problem Based Learning Model with Experimental and Project Methods. Jurnal Ilmiah Pendidikan Fisika Al-Biruni. https://doi.org/10.24042/jipfalbiruni.v10i1.8347.

Sappaile, N. (2017). Pengaruh Kompetensi Pedagogik, Kompetensi Profesional, dan Sikap Profesi Guru Tehadap Kinerja Penilaian Guru di Sekolah Dasar. Jurnal Teknologi Pendidikan, 19(1). https://doi.org/10.21009/jtp.v19i1.5334.

Sari, D. A. R. P., Tegeh, I. M., \& Pudjawan, K. (2020). Model Pembelajaran Value Clarification Technique Berbantuan Media Microsoft Powerpoint Untuk Meningkatkan Hasil Belajar PKn. Jurnal Edutech Undiksha. https://doi.org/10.23887/jeu.v8i2.29071.

Sökmen, Y. (2021). The role of self-efficacy in the relationship between the learning environment and student engagement. Educational Studies, 47(1), 19-37. https://doi.org/10.1080/03055698.2019.1665986.

Sudirman, S., Kistiono, K., Akhsan, H., \& Ariska, M. (2020). Pengembangan Instrumen Penilaian Pengetahuan, Sikap Dan Keterampilan Ipa Berbasis Berpikir Kritis Pada Konsep Listrik Siswa SMP. Jurnal Inovasi Dan Pembelajaran Fisika. https://doi.org/10.36706/jipf.v7i1.10903.

Sukendar, A., Usman, H., \& Jabar, C. S. A. (2019). Teaching-loving-caring (asah-asih-asuh) and semi-military education on character education management. Cakrawala Pendidikan. https://doi.org/10.21831/cp.v38i2.24452.

Sun, T., \& Wang, C. (2020). College students' writing self-efficacy and writing selfregulated learning strategies in learning English as a foreign language. System, 90. https://doi.org/10.1016/j.system.2020.102221. 
Susilawati, A., Hernani, H., \& Sinaga, P. (2017). The Application of Project-Based Learning Using Mind Maps To Improve Students' Environmental Attitudes Towards Waste Management in Junior High Schools. International Journal of Education, 9(2), 120125. https://doi.org/10.17509/ije.v9i2.5466.

Susongko, P., \& Afrizal, T. (2018). The determinant factors analysis of Indonesian students' environmental awareness in pisa 2015. Jurnal Pendidikan IPA Indonesia. https://doi.org/10.15294/jpii.v7i4.10684.

Trautner, M., \& Schwinger, M. (2020). Integrating the concepts self-efficacy and motivation regulation: How do self-efficacy beliefs for motivation regulation influence selfregulatory success? Learning and Individual Differences. https://doi.org/10.1016/j.lindif.2020.101890.

Tseng, H., Yi, X., \& Yeh, H. T. (2019). Learning-related soft skills among online business students in higher education: Grade level and managerial role differences in selfregulation, motivation, and social skill. Computers in Human Behavior, 95. https://doi.org/10.1016/j.chb.2018.11.035.

Wijaya, T. T., Ying, Z., Purnama, A., \& Hermita, N. (2020). Indonesian students' learning attitude towards online learning during the coronavirus pandemic. Psychology, Evaluation, and Technology in Educational Research, 3(1). https://doi.org/10.33292/petier.v3i1.56.

Wilde, N., \& Hsu, A. (2019). The Influence of General Self-Efficacy on the Interpretation of Vicarious Experience Information Within Online Learning. International Journal of Educational Technology in Higher Education, 16(1), 1-20. https://doi.org/10.1186/s41239-019-0158-x.

Winarti, P. (2021). Analisis Kesulitan Belajar Mahasiswa dalam Perkuliahan Konsep Dasar IPA Fisika Secara Daring di Masa Pandemi Covid-19. Jurnal Komunikasi Pendidikan. https://doi.org/10.32585/jkp.v5i1.1076.

Wong, W. C. W., Sun, W. H., Chia, S. M. C., Tucker, J. D., Mak, W. P. H., Song, L., Choi, K. W. Y., Lau, S. T. H., \& Wan, E. Y. F. (2020). Effectiveness of a Peer-Led WebBased Intervention to Improve General Self-Efficacy in Using Dating Apps among Young Adults: Randomized Clustered Trial. Journal of Medical Internet Research. https://doi.org/10.2196/16378.

Wu, C. T., Agrawal, D. C., Huang, W. Y., Hsu, H. C., Yang, S. J., Huang, S. L., \& Lin, Y. S. (2019). Functionality Analysis of Spent Coffee Ground Extracts Obtained by the Hydrothermal Method. Journal of Chemistry. https://doi.org/10.1155/2019/4671438.

Zysberg, L., \& Schwabsky, N. (2020). School climate, academic self-efficacy and student achievement. Educational Psychology, $\quad 0(0), \quad 1-16$. https://doi.org/10.1080/01443410.2020.1813690. 